\title{
BIOLOGICAL FACTORS TO OPTIMIZE ROOTING AND SHOOT MULTIPLICATION ON MICRO-CUTTINGS OF VOLKAMER LEMON (Citrus volkameriana Ten.) ROOTSTOCK \\ Samaan,L.G.;M.I.EL-Kady; A. M. Shalan and Lamiaa M. Mohamed. Pomology Department, Agriculture College, the University of Mansoura, Egypt.
}

ABSTRACT

The present investigation was conducted during the period between 2012 till 2013 in the Tissue Culture Laboratory of Horticulture Department, Faculty of Agriculture, the University of Mansoura, Egypt. Seeds of volkamer lemon rootstock were grown in vitro on Murashige and Skoog (1962) basal medium at full strength, hypocotyls of the resulted plantlets used as source to prepare micro-cuttings. Microcuttings before cultured on the same medium subjected to five treatments included infection with Agrobacterium rhizogenes and addition of antioxidant (Vitamin $\mathrm{B}_{12}$ ) at 1.0 or $1.5 \mathrm{mg} / \mathrm{L}$ either solely or in combinations. Untreated control micro-cuttings cultured on the same medium were considered. Representative samples were taken at random at $15^{\text {th }}$ day later treatment date to be used for determining four internal chemical constituents present in the treated micro-cuttings. Five weeks later the effect of such treatments on adventitious roots induction and shoots multiplication evaluated through measurement of concerned parameters. The obtained results pointed to the treatment of $A$. rhizogenes inoculation in the presence of vitamin $B_{12}$ at $1.5 \mathrm{mg} / \mathrm{L}$ in culture medium " $\mathrm{T}_{5}$ " to be the most effective one to produce the best rooting performance, root number and diameter as well as roots fresh and dry weights. The same treatment also increased rooting $\%$ and roots length over the control microcuttings as well as it causes an increase on carbohydrates, nitrogen contents, phenols content and $\mathrm{C} / \mathrm{N}$ ratio. Otherwise, it showed an inferior effects on start rooting, explants survival\% and rooting\% compared with vitamin $B_{12}$ treatments " $T_{2} \& T_{3}$ " effect. Since the later two treatments succeeded to record significantly the earliest start rooting, the highest frequency of micro-cutting survival and rooting percentages. It is worth to say herein that the treatment of $A$. rhizogenes inoculation only " $\mathrm{T}_{1}$ " also has a positive effect to early start rooting and to enhance chemical constituents determined in basal part of treated micro-cuttings.

Keywords: Volkamer lemon, Rutaceae, Hypocotyls, Micro-cuttings, Agrobacterium rhizogenes, Vitamin $\mathrm{B}_{12}$, Rooting, Shoot multiplication, Root parameters, Shoot parameters.

\section{INTRODUCTION}

New plants developed from the seeds in most cases will be genetically variable and each one will present a new combination of genes brought by meiotic division. Otherwise, plants produced asexually are considered as an extension of the somatic cell line of one individual. A Large number of fruit trees propagated through asexual number of techniques carry out in greenhouse environment or in vitro propagation. They are often propagated by cutting types. In some cases, cuttings are difficult to root and it was possible to activate root induction and/or improve the formed roots with application of certain co-factors (Nag et al., 2001 and Rugini et al., 1993). 
However, the difficulty of rooting is still one of the major obstacles to successful micro-propagation.

Agrobacterium rhizogenes examined in the present investigation because it is not technically a pathogenic bacterium to plants, no dramatic crop loss, nor pathological symptoms exist in plants transformed by this bacterium (Strobel and Nachimas, 1985). Moreover, the same authors reported that $A$. rhizogenes apparently restricts itself to the pericycle, the organism does not destroy or otherwise degrade tissue and seems to be compatible with plant cells culture. The promoting effect of this bacterium to stimulate adventitious roots induction was described in the work of McAfee et al. (1993) and Aronen et al. (1996) who stated that $A$. rhizogenes significantly stimulated rooting without genetically transforming the plants, would alleviate the concerns over release of genetically modified organisms with the benefit of increased rooting. In the same line, Haggman and Aronen, (2000) and Zhu et al. (2001) attributed induction of roots in woody plants as a result of infection with bacterial cells to incorporate the rol/b bacterial gene and/or secretion of compounds that stimulate rooting. A similar statement was reported by Felker et al. (2005), who attributed stimulated rooting of difficult to root woody species by $A$. rhizogenes inoculation to transforming the tissue around the pericycle to induce roots and without transforming the roots by secretion of growth promoting substances.

As for fruit trees, certain attempts to overcome difficult to root cuttings have been carried out using $A$. rhizogenes. The authors reported successful rooting on infected micro-cuttings of kiwi (Rugini, 1991), apple (Sutter and Luza, 1993), almond (Damiano et al., 1995) and walnut (Caboni et al., 1996). The transformation of micro-cuttings by $A$. rhizogenes seems to be an excellent way to induce adventitious roots and improve rooting on the infected micro-cuttings.

Vitamin $\mathrm{B}_{12}$ (antioxidant) works in close participation with $A$. rhizogenes in the current study is based on the main function of antioxidants in protecting cells from oxidative injury throughout scavenging the created free radicals (Award et al., 2001 and Kondo et al., 2005). Likewise, it is important as a cofactor for characterization of certain enzymes, which are required in all organisms for large number of biological substances as well as its deficiency resulted in decrease creation of thyamidylic acid and purine nucleotide precursor of DNA synthesis, which is necessary for normal cell division. Otherwise, its sufficient works with others (folate) in synthesis of the building block for nucleic acids (DNA and RNA), which are involved in the synthesis of proteins as activator of amino acids as well as carbohydrates and fats metabolism (Elchel et al., 1995 and Cannon et al., 2002).

It is worth to say herein that cell division is the main process to develop adventitious roots in stem cuttings. This statement was previously reported by Hartmann et al. (2010), who divided the development process of adventitious roots in stem cuttings into three stages. They all depend on cell division starting of a group of cells returned to the meristematic condition (the root initials), continue dividing forming groups of many small cells, which develop into root primordia. Cell division continues and soon each group of cells takes on the appearance of root tip. A vascular system develops in the new root 
primordium and becomes connected to the adjacent vascular bundle. The root tip continues to grow outward through the cortex, emerging from the epidermis of the stem. Therefore, the necessary root and shoot systems or both are making propagation by cuttings possible.

Consequently, the present investigation was designed to examine the ability of $A$. rhizogenes bacterial suspension in the presence or absence of vitamin $B_{12}$ (antioxidant) at two concentrations $(1.0$ and $1.5 \mathrm{mg} / \mathrm{L})$ as well as vitamin $B_{12}$ in culture medium (solely treatments) to activate induction of adventitious roots and shoot multiplication on the treated volkamer lemon micro-cuttings in vitro cultured on MS basal medium. Untreated control microcuttings were considered in that respect. Evaluation of the nature of the resulted adventitious roots and shoots through the measurement of concerned parameters was estimated in order to achieve a successful transfer to the field.

\section{MATERIALS AND METHODS}

The present study was carried out during the period between 2012 to 2013 in the Tissue Culture Laboratory of Horticulture Department, College of Agriculture, the University of Mansoura, EL-Mansoura, Egypt. It was directed to examine the ability of infected basal part of volkamer lemon micro-cuttings with $A$. rhizogenes cells and cultured in MS basal medium supplemented with vitamin $B_{12}$ at two concentrations either individually or in combinations to improve adventitious root formation and root parameters as well as induce shoots multiplication from adventitious buds.

In vitro micro-propagated explants sourced from plantlet hypocotyls of $2 \mathrm{~cm}$ long and one millimeter diameter. Plantlets produced from germinated clean sterilized seeds of volkamer lemon (Citrus volkameriana Ten.) rootstock. The source of seeds was fruits at ripe stage obtained from fruiting volkamer trees grown in a private orchard. Murashige and Skoog basal medium at full strength hormones-free used as germination medium. Seeds cultured in jars $(12 \times 6 \mathrm{~cm}) 3$ seeds each, transformed to plant growth room at $25^{\circ} \mathrm{C}$ in complete darkness for one week then exposed to continuous lighting for 4 weeks. Uniform plantlets at 40-day-old were selected to prepare hypocotyl explants (micro-cuttings).

\section{Bacterial strain and cultivation}

Agrobacterium rhizogenes strain DSM30200 sourced from Cairo Mircen Laboratory was examined in this experiment. The bacterial cells were aerobically cultured on Luria Bertani (LB) medium composed of tryptone ( $10.0 \mathrm{~g} / \mathrm{L})$, yeast extract $(5.0 \mathrm{~g} / \mathrm{L}), \mathrm{Na} \mathrm{CL}(10.0 \mathrm{~g} / \mathrm{L})$, agar $(15.0 \mathrm{~g} / \mathrm{L})$ and at $\mathrm{pH}$ 7 (Draper et al., 1988). Bacterial inoculated in LB medium and left 3 days at $27 \pm 1^{\circ} \mathrm{C}$. Transformation was done as a single colony used to inoculate $5 \mathrm{ml}$ of LB liquid medium and grow overnight at the same temperature under continuous shaking at $120 \mathrm{rpm}$. One milliliter of overnight grown Agrobacterium culture was used to inoculate $25 \mathrm{ml}$ of LB medium at $27 \pm 1^{\circ} \mathrm{C}$, shaken till an optical density reading reached 0.6 at $600 \mathrm{~nm}$ wave lengths, followed by centrifugation under cooling at $4200 \mathrm{rpm}$ for $20 \mathrm{~min}$. The 
supernatant was discarded and Agrobacterium cells precipitate pallet was suspended in $25 \mathrm{ml}$ of MS liquid basal medium.

\section{Agrobacterium rhizogenes infection procedure}

Infection process was carried out according to the technique described by Damiano et al. (1995). The basal part $(5.0 \mathrm{~mm})$ of fresh wounded microcuttings was dipped in $0.5 \mathrm{ml}$ bacterial suspension for $24 \mathrm{hrs}$ in complete darkness. Before the beginning of cultivation process on MS basal medium. The excess of bacterial cells suspension on the inoculated micro-cuttings was absorbed through sterile filter papers.

\section{Micro-cuttings culturing}

Infected explants were cultured for $48 \mathrm{hrs}$ on MS basal medium(Table 1) phytohormones and antibiotics-free in the presence or absent of vitamin $B_{12}$ (Cyanocoblamin) antioxidant treatments. Afterwards, explants (microcuttings) were re-cultured on the same medium containing the antibiotic Cefotaxime $(500 \mathrm{mg} / \mathrm{L})$ to inhibit further bacteria growth. Culturing process was in complete darkness for 10 days, however the upper parts were exposed to white light (1500 lux) for 16 hrs photoperiod provided by white fluorescent tubes at $27 \pm 1^{\circ} \mathrm{C}$ and the basal parts left in the darkness (Damiano \& Monticelli, 1998 and Abou Rayya et al., 2010). To avoid the side effect of applied antibiotic in the medium, three days later the tested microcuttings transformed and re-cultured on the same medium antibiotic-free.

\section{Acclimatization of seedlings}

Seedlings produced from the tested treatments were carefully taken out the glass tubes, washed thoroughly with sterile water at $30^{\circ} \mathrm{C}$ to remove any carry out of the medium components and to eliminate any contamination may occurred around the roots. The next step was transplanted to proper agriculture pots containing sterilized mixture of peat moss and sand $(1: 1 \mathrm{v} / \mathrm{v})$ by autoclaved at $121^{\circ} \mathrm{C}$ and $1.4 \mathrm{~kg} / \mathrm{cm}^{3}$ pressure. The planted pots transformed to glass boxes $(100 \times 60 \times 25 \mathrm{Cm})$ covered with white sheet of polyethylene for two weeks in the laboratory in order to keep the seedlings on a high relative humidity. Water and hogland solution were added to the bottom of each box at $50 \mathrm{ml}$ in height, one week later they were transferred to the greenhouse.

\section{Tested treatments}

The examined treatments on volkamer lemon micro-cuttings 5 weeks later culturing date could be expressed as follows:

Tc- Uninfected micro-cuttings cultured on MS basal medium to serve as control.

$\mathrm{T}_{1}$ - Dipping the basal part of micro-cuttings $(5.0 \mathrm{~mm})$ in bacterial suspension for $24 \mathrm{hrs}$ and cultured on MS basal medium.

$\mathrm{T}_{2}$ - Micro-cuttings cultured on MS basal medium in the presence of vitamin $B_{12}$ antioxidant at $1.0 \mathrm{mg} / \mathrm{L}$.

$\mathrm{T}_{3}$ - Micro-cuttings cultured on MS basal medium in the presence of vitamin $\mathrm{B}_{12}$ antioxidant at $1.5 \mathrm{mg} / \mathrm{L}$.

$\mathrm{T}_{4}$ - Dipping basal part of micro-cuttings in bacterial suspension for $24 \mathrm{hrs}$ and cultured on MS basal medium in the presence of vitamin $B_{12}$ antioxidant at $1.0 \mathrm{mg} / \mathrm{L}$. 
$\mathrm{T}_{5^{-}}$Dipping basal part of micro-cuttings in bacterial suspension for $24 \mathrm{hrs}$ and cultured on MS basal medium in the presence of vitamin $B_{12}$ antioxidant at 1.5 $\mathrm{mg} / \mathrm{L}$.

\section{Evaluation parameters}

The tested treatments were evaluated throughout measurement of two parameter types measured on the treated and cultured micro-cuttings of volkamer lemon rootstock at 5-week-old .These types included:

\section{A. Root physical parameters}

These parameters concerned with the whole cultured micro-cuttings and induced adventitious roots at 5-week-old from culturing date. They could be presented as follows:

$A_{1}$-Start of rooting on treated and cultured micro-cuttings in days.

$A_{2}$-Micro-cuttings survival percentage

It was calculated for in vitro cultured micro-cuttings under treatments adopted the following equation:

$$
\text { Survival\%= } \frac{\text { Number of survival micro-cuttings }}{\text { Total number of cultured micro-cuttings }} \times 100
$$

$\mathrm{A}_{3}$-Micro-cuttings rooting percentage

It was calculated for in vitro cultured micro-cuttings under treatments using the following equation:

$$
\text { Rooting } \%=\frac{\text { Number of rooted micro-cuttings }}{\text { Total number of cultured micro-cuttings }} \times 100
$$

$\mathrm{A}_{4}$-Average adventitious roots number per micro-cutting.

$A_{5}$-Average adventitious root length per micro-cutting in $\mathrm{cm}$.

$\mathrm{A}_{6}$-Average adventitious root diameter per micro-cutting in $\mathrm{mm}$.

$A_{7}$-Average adventitious roots fresh weight per micro-cutting in $\mathrm{mg}$.

$\mathrm{A}_{8}$-Average adventitious roots dry weight per micro-cuttings in $\mathrm{mg}$.

\section{B- Shoot physical parameters}

This part of study concerned with the measurement of shoot multiplication parameters derived during proliferation period (sprouting) from adventitious buds on micro-cuttings stem. The parameters considered in that respect were:

$B_{1}$ - Average shoots number per micro-cutting.

$B_{2}$ - Average shoot length per micro-cutting in $\mathrm{cm}$.

$B_{3}$ - Average shoot diameter per micro-cutting in $\mathrm{mm}$.

$\mathrm{B}_{4}$ - Average leaves number per micro-cutting.

$\mathrm{B}_{5}$ - Average shoots fresh weight per micro-cutting in $\mathrm{mg}$.

$\mathrm{B}_{6}$ - Average shoots dry weight per micro-cutting in $\mathrm{mg}$.

\section{C-Chemical parameters}

Representative samples of three micro-cuttings per treatment were taken at random in $15^{\text {th }}$ day from treatment date to be used for determining four internal chemical determinations. They immediately transferred to the 
laboratory of Pomology Department, dried in an electric oven at $50^{\circ} \mathrm{Cto}$ a constant weight (48 hrs), ground into a fine powder and kept for chemical determinations. Chemical parameters studied in the present research were determined at the basal part of the treated micro-cuttings plus control ones $(5.0 \mathrm{ml})$ after 15 days from treatment date. Chemical parameters determined in this part of research were total carbohydrates, total nitrogen contents, $\mathrm{C} / \mathrm{N}$ ratio and phenols content.

1-Carbohydrates content: Total carbohydrates determined according to the method described by Hedge and Hofreiter, (1962) .The obtained results presented as percentage on the basis of dry weight (DW).

2-Nitrogen contents: Nitrogen contents determined through digestion samples according to the method described by Peterburgski, (1968). The modified Micro-Kjeldah apparatus of Parner and Wagner was used for this determination as described by Jones et al. (1991) and total nitrogen valued according to A.O.A.C (1984). The results presented as percentage on the basis of dry weight (DW).

3-C/N ratio calculations: This ratio was calculated using the respective values recorded for both carbohydrate and nitrogen contents.

4-Phenols content: The method described by Malick and Singh, (1980) was followed and the concentrations were estimated and expressed as $\mathrm{mg}$ catechol / $100 \mathrm{~g}$ on fresh weight basis (FW).

\section{Experiment design}

Experiment was designed in a randomized complete block design with 6 treatments on the tested micro cuttings, 3 replicates with 10 cultured tubes each. This means 30 micro-cuttings per treatment.

\section{Statistical analysis}

The obtained data were subjected to analysis of variance (ANOVA) by using "Genstat 11.1" (2008). The mean comparisons were performed by the least significant difference value (LSD) at $5 \%$ of probability according to Gomez and Gomez. (1984).

Table (1): Murashige and Skoog (1962) cultured medium used.

\begin{tabular}{|c|c|}
\hline Ingredients & $\mathrm{mg} / \mathrm{L}$ \\
\hline $\mathrm{NH}_{4} \mathrm{NO}_{3}$ & 1650 \\
\hline $\mathrm{KNO}_{3}$ & 1900 \\
\hline $\mathrm{CaCl}_{2} .2 \mathrm{H}_{2} \mathrm{O}$ & 440 \\
\hline $\mathrm{MgSO}_{4} .7 \mathrm{H}_{2} \mathrm{O}$ & 370 \\
\hline $\mathrm{FeSO}_{4} .7 \mathrm{H}_{2} \mathrm{O}$ & 27.8 \\
\hline $\mathrm{Na}_{2} \mathrm{EDTA}$ & 37.3 \\
\hline $\mathrm{MnSO}_{4} \cdot 4 \mathrm{H}_{2} \mathrm{O}$ & 22.3 \\
\hline $\mathrm{H}_{3} \mathrm{BO}_{3}$ & 8.6 \\
\hline $\mathrm{KI}$ & 0.83 \\
\hline $\mathrm{CuSO}_{4} \cdot 5 \mathrm{H}_{2} \mathrm{O}$ & 0.025 \\
\hline $\mathrm{CoCl}_{2} .2 \mathrm{H}_{2} \mathrm{O}$ & 0.025 \\
\hline $\mathrm{KH}_{2} \mathrm{PO}_{4}$ & 170 \\
\hline $\mathrm{ZnSO}_{4} \cdot 7 \mathrm{H}_{2} \mathrm{O}$ & 8.6 \\
\hline $\mathrm{Na}_{2} \mathrm{MoO}_{4} \cdot 2 \mathrm{H}_{2} \mathrm{O}$ & 0.25 \\
\hline
\end{tabular}




\section{RESULTS}

The present research is one of the recent attempts, it examined the possibility of using of Agrobacterium rhizogenes strain DSM30200 in the presence or absence of vitamin $B_{12}$ antioxidant to improve rooting on microcuttings of Volkamer lemon rootstock micro-propagated in vitro on MS basal medium. The nature of induced adventitious roots and shoot multiplication under proliferation stage were evaluated in order to achieve a successful transfer to the field.

\section{1-Adventitious root formation and rooting parameters}

Adventitious roots induced on the treated micro-cuttings were evaluated through the measurements of five physical root parameters included average roots number, root length, root diameter, roots fresh and roots dry weights per micro-cutting. In addition to three other estimations of roots formation included start of rooting in days, micro-cuttings rooting \% and micro-cuttings survival \%. The concerned data were presented in Tables (1\&2) and illustrated in Figure (1\&2). From these tables and figures, it was cleared a significant variation among the effect of examined treatments. Infected basal part of micro-cuttings with Agrobacterium rhizogenes cells and cultured on MS basal medium " $T_{1}$ "succeeded, relatively, to early start rooting (15 days) and to produce adventitious roots of significantly higher average number (3.33 roots), length $(3.33 \mathrm{~cm})$, diameter $(1.09 \mathrm{~mm})$, fresh weight $(48.10 \mathrm{mg})$ and dry weight $(2.20 \mathrm{mg})$ if compared with the untreated control microcuttings cultivated on the same medium. The corresponding average values for the control were 13.33 days, 2.00 roots, $1.33 \mathrm{~cm}, 1.01 \mathrm{~mm}, 11.00 \mathrm{mg}$ and $0.51 \mathrm{mg}$, respectively.

Adventitious roots were initiated on the cut surface of Volkamer lemon micro-cuttings cultured on MS basal medium supplemented with vitamin $B_{12}$ solution either at $1.0 \mathrm{mg} / \mathrm{L}$ and $1.5 \mathrm{mg} / \mathrm{L}$ " $\mathrm{T}_{2} \& \mathrm{~T}_{3}$ ". The concerned results of the treated micro-cuttings in Tables (1\&2) and illustrated in Figure (1) showed significantly the earliest start rooting (10 days for both), the highest frequency of micro-cuttings survival percentages (91.33 and $94.67 \%$ ) and rooting percentages (91.00 and $94.67 \%$, respectively) as well as they measured average root length with the values of 5.67 and $6.17 \mathrm{~cm}$, respectively. Microcuttings of both treatments also produced adventitious roots of significantly higher root diameter (1.08 $\mathrm{mm}$ for both), roots fresh weight (13.56 and 19.20 $\mathrm{mg}$ ) and root dry weight ( 0.71 and $0.91 \mathrm{mg}$, respectively) if compared with the untreated control micro-cuttings cultured on the same medium and conditions. The later micro-cuttings respectively, tabulated the values $1.01 \mathrm{~mm}, 11.00 \mathrm{mg}$ and $0.51 \mathrm{mg}$. The treatment " $\mathrm{T}_{3}$ " was mostly the super one in that respect.

As for the effect of the combined treatments " $T_{4} \& T_{5}$ " on inducing adventitious roots, It is worthy to say that infected basal part of micro-cuttings with $A$. rhizogenes cells followed by cultured on MS basal medium supplemented with vitamin $B_{12}$ solution at $1.5 \mathrm{mg} / \mathrm{L}$ " $\mathrm{T}_{5}$ " succeeded to measure significantly the highest values of average roots number (4.00 roots), root diameter $(1.20 \mathrm{~mm})$, roots fresh and dry weights $(61.43$ and 3.60 
$\mathrm{mg}$, respectively) per micro-cutting. Moreover this combined treatment compared to the control one, it increased average roots length from $1.33 \mathrm{~cm}$ to $3.33 \mathrm{~cm}$ over the untreated control micro-cuttings cultured in vitro on MS basal medium (Tables 1\&2 and Figure 2). On the other hand, the concerned results in Tables (1\&2) indicated that infected basal part of micro-cuttings with bacterial cells followed by cultured on MS basal medium in the presence of vitamin $\mathrm{B}_{12}$ solution either at 1.0 or $1.5 \mathrm{mg} / \mathrm{L}$ " $\mathrm{T}_{4} \& \mathrm{Ts}$ " obviously delayed start rooting by 26.00 and 27.33 days, respectively. In addition, the same microcuttings tabulated the lowest frequency of survival explants\% with the value of $50.33 \%$ for both treatments.

Table (2): Effect of Agrobacterium rhizogenes inoculation and vitamin $B_{12}$ antioxidant $\left(V B_{12}\right)$ in culture medium either solely or in combinations on starting rooting, survival \% and rooting \% of Volkamer lemon root stock micro-cuttings resulted in vitro up on time culture for 5 weeks.

\begin{tabular}{|c|c|c|c|c|c|}
\hline Treatments & Symbol & $\begin{array}{l}\text { No. of micro } \\
\text { cuttings }\end{array}$ & $\begin{array}{l}\text { Start of } \\
\text { rooting } \\
\text { (days) }\end{array}$ & $\begin{array}{c}\text { Survival } \\
\text { micro- } \\
\text { cuttings } \\
\%\end{array}$ & $\begin{array}{c}\text { Micro-cuttings } \\
\text { rooting } \\
\%\end{array}$ \\
\hline Control & Tc & 30 & $13.33^{*}$ & 74.67 & 51.00 \\
\hline A. rhizogenes & T1 & 30 & 15.00 & 64.67 & 51.00 \\
\hline $\mathrm{VB}_{12}$ at $1.0 \mathrm{mg} / \mathrm{L}$ & T2 & 30 & 10.00 & 91.33 & 91.00 \\
\hline $\mathrm{VB}_{12}$ at $1.5 \mathrm{mg} / \mathrm{L}$ & T3 & 30 & 10.00 & 94.67 & 94.67 \\
\hline A.rhizogenes+VB $\mathrm{VB}_{12}$ at $1.0 \mathrm{mg} / \mathrm{L}$ & T4 & 30 & 26.00 & 50.33 & 35.33 \\
\hline $\begin{array}{l}\text { A. rhizogenes }+\mathrm{VB}_{12} \text { at } 1.5 \\
\mathrm{mg} / \mathrm{L}\end{array}$ & T5 & 30 & 27.33 & 50.33 & 35.67 \\
\hline LSD at $0.5 \%$ & & & 3.05 & 1.03 & 1.45 \\
\hline
\end{tabular}

${ }^{*}$ These tabulated numbers as an average values.

Table (3): Effect of Agrobacterium rhizogenes inoculation and vitamin $B_{12}$ antioxidant $\left(V B_{12}\right)$ in culture medium either solely or in combinations on five root physical parameters measured on Volkamer lemon rooted micro-cuttings resulted in vitro up on time culture for 5 weeks.

\begin{tabular}{|l|c|c|c|c|c|c|}
\hline Treatments & Symbol & $\begin{array}{c}\text { Roots } \\
\text { number }\end{array}$ & $\begin{array}{c}\text { Roots } \\
\text { length } \\
\text { (cm) }\end{array}$ & $\begin{array}{c}\text { Roots } \\
\text { diameter } \\
\text { (mm) }\end{array}$ & $\begin{array}{c}\text { Roots fresh } \\
\text { weight } \\
\text { (mg) }\end{array}$ & $\begin{array}{c}\text { Roots dry } \\
\text { weight } \\
\text { (mg) }\end{array}$ \\
\hline Control & Tc & $2.00^{*}$ & 1.33 & 1.01 & 11.00 & 0.51 \\
\hline$A$. rhizogenes & T1 & 3.33 & 3.33 & 1.09 & 48.10 & 2.20 \\
\hline $\mathrm{VB}_{12}$ at $1.0 \mathrm{mg} / \mathrm{L}$ & T2 & 1.67 & 5.67 & 1.08 & 13.56 & 0.71 \\
\hline $\mathrm{VB}_{12}$ at $1.5 \mathrm{mg} / \mathrm{L}$ & T3 & 1.33 & 6.17 & 1.08 & 19.20 & 0.91 \\
\hline $\begin{array}{l}\text { A. rhizogenes } \\
\mathrm{VB}_{12} \text { at } 1.0 \mathrm{mg} / \mathrm{L}\end{array}$ & T4 & 1.67 & 2.67 & 1.10 & 44.20 & 1.46 \\
\hline $\begin{array}{l}\text { A. rhizogenes + } \\
\mathrm{VB}_{12} \text { at } 1.5 \mathrm{mg} / \mathrm{L}\end{array}$ & T5 & 4.00 & 3.33 & 1.20 & 61.43 & 3.60 \\
\hline LSD 5\% & 0.04 & 0.04 & 0.04 & 0.73 & 0.15 \\
\hline
\end{tabular}

*These tabulated numbers as an average values. 
Figure (1): Photos showing the effect of vitamin $B_{12}$ in MS basal medium on adventitious root and shoot parameters of Volkamer lemon rootstock micro-cuttings under the treatments described in the method. 
Samaan,L.G. et al.

Figure (2):Photos showing the effect of Agrobacterium rhizogenes inoculation with and without vitamin $B_{12}$ in MS basal medium on root and shoot parameters of Volkamer rootstock microcuttings under the treatments described in the method. 


\section{1- Shoot multiplication and parameters}

Results of shoots multiplication parameters of the treated volkamer lemon micro-cuttings were presented in Table (4) and illustrated in Figures (1\&2). From these tables and figures, it was proved that the treatment of $A$. rhizogenes inoculation and culturing micro-cuttings on MS basal medium " $\mathrm{T}_{1}$ " has high positive effects on shoot parameters measured. It tabulated significantly the highest average shoots number per micro-cutting (3.00 shoots) and shoots length $(3.33 \mathrm{~cm})$, shoot diameter $(2.07 \mathrm{~mm})$ and leaves number (10.01 leaves) per micro-cutting.

Concerning the effects of two vitamin $B_{12}$ treatments, the concerned results in Table (4) and illustrated in Figure (1) clearly indicate that such treatments had an increasing effects on certain shoot parameters with special emphasis to " $\mathrm{T}_{3}$ " one. It tabulated an average shoot number and length (1.33 shoots and $2.33 \mathrm{~cm}$ ) along with leaves numbers (and 5.33 leaves) higher than similar measures on micro-cuttings of the " $\mathrm{T}_{2}$ " treatment. The same was true with shoots fresh and dry weights per micro-cutting. The concerned data of " $\mathrm{T}_{3}$ " respectively, were 42.10 and $1.46 \mathrm{mg}$. The corresponding values of " $\mathrm{T}_{2}$ " for these shoot parameters were 1.00 shoots, $2.17 \mathrm{~cm}$. 4.32 leaves, $28.10 \mathrm{mg}$ and $1.20 \mathrm{mg}$. The opposite was true in case of average shoot diameter, since " $\mathrm{T}_{2}$ " recorded value higher than those of " $\mathrm{T}_{3}$ ". They valued average shoot diameter 2.03 and $1.06 \mathrm{~mm}$, respectively.

Regarding to the combined treatments $\left(T_{4} \& T_{5}\right)$, data in Table (4) and illustrated in Figure (2) showed that the optimal shoot multiplication was achieved on micro-cuttings inoculated with bacterial cells followed by cultured on MS basal medium supplemented with vitamin $B_{12}$ solution at $1.5 \mathrm{mg} / \mathrm{L}$ " $\mathrm{T}_{5}$ ". Micro-cuttings under this treatment resulted in the best shoots performance with the highest values of average shoots number, shoot diameter, leaves number as well as shoot fresh and dry weights. Such values were, 2.33, $2.17 \mathrm{~mm}, 10.90$ leaves, $56.10 \mathrm{mg}$ and $3.02 \mathrm{mg}$, respectively. Moreover this combined treatment also increased average shoots length over the untreated control micro-cuttings cultured in vitro on MS basal medium. This increase for shoots length was from $1.50 \mathrm{~cm}$ to $2.17 \mathrm{~cm}$.

\begin{tabular}{|c|c|c|c|c|c|r|r|}
\hline Treatments & Symbol & $\begin{array}{c}\text { Shoots } \\
\text { number }\end{array}$ & $\begin{array}{c}\text { Shoots } \\
\text { length } \\
(\mathbf{c m})\end{array}$ & $\begin{array}{r}\text { Shoot } \\
\text { diameters } \\
(\mathbf{m m})\end{array}$ & $\begin{array}{r}\text { Shoots } \\
\text { feaves } \\
\text { number } \\
\text { weight } \\
(\mathbf{m g})\end{array}$ & $\begin{array}{r}\text { Shoots dry } \\
\text { weight } \\
(\mathbf{m g})\end{array}$ \\
\hline
\end{tabular}




\begin{tabular}{|c|c|c|c|c|c|c|c|}
\hline Control & Tc & 1.00 * & 1.50 & 1.03 & 2.67 & 18.10 & 0.94 \\
\hline A. rhizogenes & T1 & 3.00 & 3.33 & 2.07 & 10.01 & 70.37 & 5.10 \\
\hline 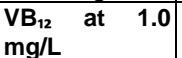 & T2 & 1.00 & 2.17 & 2.03 & 4.32 & 28.10 & 1.20 \\
\hline 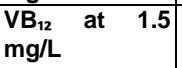 & T3 & 1.33 & 2.33 & 1.06 & 5.33 & 42.10 & 1.46 \\
\hline $\begin{array}{l}\text { A. rhizogenes } \\
+\mathrm{VB}_{12} \text { at } 1.0 \\
\end{array}$ & T4 & 1.00 & 2.17 & 1.38 & 5.00 & 39.50 & 1.30 \\
\hline $\begin{array}{l}\text { A. rhizogenes } \\
+\mathrm{VB}_{12} \text { at } 1.5\end{array}$ & T5 & 2.33 & 2.17 & 2.07 & 10.90 & 56.10 & 3.02 \\
\hline LSD at $0.5 \%$ & & 0.93 & 0.78 & 0.39 & 0.073 & 0.37 & 0.13 \\
\hline
\end{tabular}

Table (4): Effect of Agrobacterium inoculation and vitamin $B_{12}(V)$ antioxidant in culture medium either solely or in combinations on shoot formation parameters measured on Volkamer lemon micro-cuttings resulted in vitro during shoot proliferation period up on time culture for 5 weeks.

*These tabulated numbers as an average values.

The rooted plantlets were successfully acclimatized in laboratory for 2 weeks then transported to the greenhouse condition and grow with no morphological variations (Figure 3)

Figure (3): Photos showing acclimatized plantlets in green house produced from volkamer lemon micro-cuttings under treatments described in the method.

11- Changes in chemical constituents Involved in formed adventitious roots 
Adventitious roots formation process and root parameters on micro-cutting of volkamer lemon rootstocks under study were activated corresponding with the effect of tested treatments. The treatments that have the ability to make an increasing effect on carbohydrates, nitrogen contents and phenols as well as $\mathrm{C} / \mathrm{N}$ Ratio succeeded to form adventitious roots of higher qualities. Therefore, volkamer lemon treated micro-cuttings specially under the treatments of infected micro-cuttings with Agrobacterium rhizogenes cells before in vitro culturing on MS (1962) basal medium " $\mathrm{T}_{1}$ " and the combined treatment between Agrobacterium rhizogenes inoculation and additive antioxidant at $1.5 \mathrm{mg} / \mathrm{L}$ in culture medium " $\mathrm{T}_{5}$ ". These treated micro-cuttings tabulated greater measures on root parameters and higher values for chemical constituents examined (Tables 3 and 5).

Table (5): Effect of Agrobacterium rhizogenes inoculation and vitamin $B_{12}$ antioxidant $\left(\mathrm{V}_{12}\right)$ in culture medium either solely or in combinations on chemical parameters determined on Volkamer lemon micro-cuttings resulted in vitro up on time culture for 5 weeks.

* These tabulated numbers as an average values.

\begin{tabular}{|l|c|c|c|c|c|}
\hline \multicolumn{1}{|c|}{ Treatments } & Symbol & $\begin{array}{c}\text { Total } \\
\text { carbohydrates } \\
\text { (\%DW) }\end{array}$ & $\begin{array}{c}\text { Total } \\
\text { nitrogen } \\
\%\end{array}$ & $\begin{array}{c}\mathbf{C} / \mathbf{N} \\
\text { Ratio }\end{array}$ & $\begin{array}{c}\text { Total } \\
\text { phenols } \\
\text { Mg/100g }\end{array}$ \\
\hline Control & $\mathrm{Tc}$ & 24.80 & 1.75 & 14.17 & 124 \\
\hline A. rhizogenes & $\mathrm{T}_{1}$ & 27.43 & 2.14 & 12.82 & 144 \\
\hline $\mathrm{VB}_{12}$ at $1.0 \mathrm{mg} / \mathrm{L}$ & $\mathrm{T}_{2}$ & 25.73 & 1.83 & 14.06 & 130.33 \\
\hline $\mathrm{VB}_{12}$ at $1.5 \mathrm{mg} / \mathrm{L}$ & $\mathrm{T}_{3}$ & 26.40 & 1.98 & 13.33 & 138 \\
\hline $\begin{array}{l}A . \text { rhizogenes } \\
\text { VB }\end{array}$ & $\mathrm{T}_{4}$ at 1.0 & 24.80 & 2.20 & 11.27 & 152 \\
\hline $\begin{array}{l}\text { A.rhizogenes } \\
\mathrm{VB}\end{array}$ & $\mathrm{T}_{12}$ at 1.5 & 28.33 & 2.29 & 12.37 & 158 \\
\hline $\mathrm{LSD}$ at $5 \%$ & & 0.14 & 0.08 & 0.55 & 1.68 \\
\hline
\end{tabular}

\section{DISCUSSION}

Rootstock seedlings developed from the seeds in most cases will be genetically variable and each one will present a new combination of genes brought by meiotic division. Otherwise, seedlings produced asexually are considered as an extension of the somatic cell line of one individual. A large number of economically fruit trees are propagated through asexual number of techniques carried out in greenhouse environment or in vitro culture propagation. They are often propagated by cuttings, but in some cases cuttings are difficult to root.

Micro-propagation by micro-cuttings is one of the important techniques that makes it possible to improve in vitro rooting by the application of some co-factors (Rugini et al., 1993 and Nag et al., 2001). However, the difficulty of rooting is still one of the major obstacles to successful micro-propagation. Recently, many attempts to overcome this problem have been carried out on 
different plant species using Agrobacterium rhizogenes inoculation and antioxidant (vitamin $\mathrm{B}_{12}$ ).

The results presented in this paper indicate that the use of Agrobacterium rhizogenes either solely or in combinations can be a successful approach to improve rooting on volkamer lemon micro-cuttings. As for $A$. rhizogenes, different positive responses to infection were occurred. These findings are in line with Dobingy et al. (1995), who worked on two potato cultivars and Gutierrez-Pesce et al. (1998) on cherry rootstocks. They demonstrated that hairy roots were produced after inoculation with certain strains of $A$. rhizogenes. In case of fruit trees, several authors go to results in harmony with our results. They reported successful rooting by the use of $A$. rhizogenes inoculation. They mediated transformation in fruit trees, such as apple (Sutter and Luza, 1993); almond (Damiano et al., 1995) and walnut (Caboni et al., 1996). The transformation of micro-cuttings and seedlings by these bacterial cells seem to be an excellent way to improve rooting in the treated cuttings. More recent, Damiano and Moncticelli, (1998) working on some fruit species (almond, apple, plum, Pyrus pyraster and two peach hybrids) found that $A$. rhizogenes inoculation of micro-cuttings in vitro can improve the rooting process.

Agrobacterium rhizogenes cells to stimulate rooting formation on microcuttings was also the subject of previous studies carried out by McAfee et al. (1993), who working on rooting of Pinus monticola, Pinus banksiana and Larix laricina ; Aronen et al. (1996) on Pinus sylvestris.

Root and shoot promoting effect of vitamin $B_{12}$ antioxidant solution at 1.5 $\mathrm{mg} / \mathrm{L}$ " $\mathrm{T}_{3}$ " could be explained as the higher amount of vitamin $\mathrm{B}_{12}$ in microcutting tissues, with special emphases to cells previously considered the origin of adventitious roots induction, caused an activating effect on cell division mechanism which is responsible for roots initiation and roots primordia formation. Our results of " $\mathrm{T}_{3}$ " treatment clearly supported this explanation since, such treatment tabulated the early start of rooting (10 days), the highest survival and rooting percentages (94.67 and $94.67 \%$, respectively). Furthermore, the presence of vitamin $B_{12}$ has an effective role in synthesis of food materials (Carbohydrates) in micro-cuttings which provide sufficient amount of food for root development and bud sprouting (Hartmann et al., 2010 and Bleasdale, 1984). In the same line, Tahir et al. (1998) supported the importance of carbohydrates accumulation in guava stem cuttings and other hardwood cuttings to produce number of shoots and leaves.

It is worth to say herein that the importance of carbohydrates for rooting was previously evidenced since early times. Stoutimyer and Close, (1946) reported that the photoperiod under which the stock plants is grown may exert an influence on the rooting of cuttings taken from it. They added that it may be related to carbohydrate accumulation, the best rooting often being obtained under photoperiods promoting carbohydrate increase.

The superiority of the combination treatment " $\mathrm{T}_{5}$ " to improve roots performance and increase rooting parameters could be attributed to a kind of synergistic effect between infection with bacterial cells and vitamin $B_{12}$ at 1.5 
$\mathrm{mg} / \mathrm{L}$. This means that vitamin $\mathrm{B}_{12}$ (antioxidant) works in close participation with $A$. rhizogenes in the current study. Basically the suggested synergistic effect depended on the main function of antioxidant in protecting cells from oxidative injury throughout scavenging the created free radicals and it's importance as a co-factor for characterization of certain enzymes which are required in all organisms for large number of biological substances (Award et al., 2001 and Kondo et al., 2005). Moreover, vitamin $B_{12}$ deficiency resulted in decreased creation of thyamidylic acid and purine nucleotide precursor of DNA synthesis which is necessary for normal cell division. Otherwise, its sufficient works with others (folate) in the synthesis of the building blocks for nucleic acids (DNA and RNA) and de novo of purine nucleotide synthesis. Both are involved in the synthesis of proteins as activator of amino acids as well as carbohydrates and fats metabolism (Cannon et al., 2002).

The above functions of vitamin $\mathrm{B}_{12}$, as one participant in this super combined treatment, pointed to it's important role in activating cell division which represents the main process for root initiation and formation of root primordia as well as root tips. Since previously it is well known that rooting induction mechanism started with small groups of cells in the origin source of adventitious roots in stem cuttings (cambium cells, phloem cells and vascular rays) becoming to meristematic state to create root initials, continue dividing to develop into root primordia, cell division continues and soon each group of cells takes on the appearance of a root tip which continue to grow outward (Danckwardi-lilliestorm, 1957 and Hartmann et al., 2010). In addition, the presence of vitamin $B_{12}$ in culture medium is important to provide microcuttings with sufficient food (Carbohydrates) needed for root development and bud sprouting as previously indicated by Hartmann et al. (2010) and Bleasdale, (1984). In the same line Kadota et al. (2001) reported that a number of carbohydrates affect the growth and the frequencies of shoot proliferation and development as well as produced a good result for root multiplication. Sucrose is the best source of carbon and it's hydrolyzed into glucose and fructose necessary for cell assimilation and division. Nag et al. (2001) reported that transport of carbohydrates to the base of shoot enables the cells to have the energy source needed for cell division.

As for the stimulating effect of $A$. rhizogenes inoculation, the other participant, on rooting and shoots multiplication, it was explained in studies of several authors. Damiano and Monticelli, (1998) suggested that the rooting process involves more than the transformed cells. Haggman and Aronen, (2000) and Zhu et al. (2001) attributed the bacterial effect to induce adventitious roots in carrot disks and in apple cuttings by incorporating the $\mathrm{rol} / \mathrm{B}$ bacterial gene and/or by secretion of compounds that stimulate rooting. McAfee et al. (1993) described another mechanism for hairy roots formation by $A$. rhizogenes inoculation. It transfers a part of a large plasmid known as the "Ri" (Root-inducing) plasmid. The role of bacterium in modifying the root environment by means of organic acid secretions and lowered the $\mathrm{pH}$. More recent, Felker et al. (2005) attributed the positive effect $A$. rhizogenes inoculation on stimulating rooting of difficult to root woody species to 
transforming the tissue around the pericycle inducing roots, and without transforming the roots by secretion of growth promoting substances.

This synergistic effect that we suggested herein was previously reported by Mingshan and David, (2003), who worked on radiate pine (Pinus radiate Don.) hypocotyl explants infected with two strains of $A$. rhizogenes and in vitro cultured with or without application of IBA. They found both strains induce the rooting with different rooting\% and roots number. Addition of IBA at $4.4 \mathrm{uM}$ to culture medium increased rooting on the culture hypocotyl segments inoculated with the two strains of $A$. rhizogenes. These results also go in line with previous studies carried out by Sato et al. (1991), who obtained hairy roots on Rubia tinctorum micro-cuttings (cotyledon explants) infected with cells of $A$. rhizogenes strain15834. Dobigny et al. (1995) worked on two cultivars of potato goes to a similar results. They demonstrated that induction frequency of root formation was after inoculation with two strains of $A$. rhizogenes. In the same line, Damiano and Monticelli, (1998) reported that $A$. rhizogenes can improve the rooting of some fruit trees.

Otherwise, the inferior effects of these combined treatments on delaying start rooting and decreasing explants survival \% as well as explants rooting $\%$ compared with the treatments of vitamin $B_{12}$ solution either at $1.0 \mathrm{mg} / \mathrm{L}$ " $\mathrm{T}_{2}$ " or $1.5 \mathrm{mg} / \mathrm{L}$ " $\mathrm{T}_{3}$ ", with special emphasis to the later one. This can be explained as the interaction between bacterial cells and the presence of vitamin $B_{12}$ antioxidant in culture medium minimized the activating effect of vitamin $B_{12}$ in that respect. This means a kind of antagonism was presented between infection with bacterial cells and vitamin $B_{12}$ provided to culture medium on these root performance parameters.

Generally, it could be concluded that volkamer lemon micro-cuttings when infected the base part with $A$. rhizogenes cells followed by cultured on MS basal medium supplemented with vitamin $B_{12}$ solution at $1.5 \mathrm{mg} / \mathrm{L}$ " $\mathrm{TV}_{5}$ " resulted in the best rooting parameters such as, average roots number, root diameter, roots fresh weight and root dry weight. Moreover this combined treatment also increased average micro-cuttings rooting\% and roots length over the untreated control micro-cuttings cultured in vitro on MS basal medium. The superiority of this combined treatment could be attributed to a kind of synergistic effect between infection and vitamin $B_{12}$ at $1.5 \mathrm{mg} / \mathrm{L}$. The treatment of infection with bacterial cells before micro-cuttings culturing " $\mathrm{T}_{1}$ " can be ranked the next effect in that respect, since it was enable early rooting (15 days), the middle results for root parameters and the most amenable for most shoot parameters.

Consequently, the present research succeeded to introduce an additional modern technique that can be helps in overcoming the difficulty to root cuttings which is still one of the major obstacles to successful micropropagation of the most economically important fruit trees. Furthermore, this characterized technique provides uniform rootstock seedlings true to type that insure complete similar effects on the grafted or budded scions. In addition it improves performance of the induced adventitious roots as well as increases rooting $\%$ and shoot multiplication parameters in order to achieve a 
successful transfer to the field. This in turn makes volkamer lemon good rootstock if the propagated trees are desirable.

The positive relationship between changes in chemical constituents in basal part of the treated micro-cuttings and either adventitious root parameters or shoot proliferation ones using $A$. rhizogenes plus antioxidant, could be attributed to certain evidences supported the effective role of these biochemical compounds to exert an influence on the rooting of cuttings. Carbohydrates in micro-cuttings provide sufficient amount of food for roots formation (Hartmann et al., 2010 and Bleasdale, 1984). In the same point, the former authors reported that the rooting capacity of many cuttings has been correlated with carbohydrates content. Tahir et al. (1998) confirmed the important of carbohydrates accumulation in guava stem cuttings and other hardwood cuttings to produce number of root and shoots. Additionally, Kadota et al. (2001) reported that Sucrose is the best source of energy and it hydrolyzed into glucose and fructose necessary for cell assimilation and division.

Sufficient of both carbohydrates and nitrogenous basis works with others in synthesis of the building blocks for nucleic acids (DNA and RNA). These biochemical compounds are the main source in synthesis of proteins as well as carbohydrates and fats metabolism which they all are necessary for normal cell division (Cannon et al. 2002). In that respect, previously Galle, (1965) worked on leaf cuttings of cauliflowers (Brassica oleraca) and found a marked increase in the RNA content in tissues of cuttings basal part occurred during the period in which root primordia were formed. Breen and Muraoka, (1973) with softwood cuttings of Marianna plum suggested that seasonal variation of nutrients in plant occur according to their movement connected with sink and source relationship depending upon growth rate. If the Nitrogen level in cuttings decreased below a certain level, root formation was decreased in spite of a high level of carbohydrates. A similar result was cleared in the studies of Kim et al. (1977) with Korean boxwood cuttings and Hambrick et al. (1985) with Rosa multiflora cuttings. They showed also that effect of non-rooting was related to carbohydrates content in cuttings.

As for $\mathrm{C} / \mathrm{N}$ ratio, a similar relationship of carbohydrates and $\mathrm{C} / \mathrm{N}$ ratio with root qualities was found. High $\mathrm{C} / \mathrm{N}$ ratio in hardwood stem cuttings is favorable to good rooting (Yongkweon and KiSun, 1996; Mahros, 2000 and Hussein, 2008). They added that $\mathrm{C} / \mathrm{N}$ ratio may be an important factor influencing the root ability and their levels were positively related to rooting percentage on cuttings under study.

In testing the biological activity of compounds structurally related to rooting co-factors, since early times Hess, (1962) found that the phenol compound catechol react synergistically with IAA in root production in the mung been bioassay. Bouillenne and Bouillene, (1955) suggested that oxidation of an ortho-dihydroxy phenol is one of the first step leading to root initiation. Tests using UV spectrum analysis and infrared spectroscopy indicated that the rooting factor is complex structure of high molecular weight (an indole-phenol complex). They reported also that this factor may react at the base of the cutting with specific enzyme initiating cell division leading to adventitious root formation (Hartmann and Kester, 1968; Fadl and Hartman 1967). The 
regulatory effect of phenols in this subject was indicated by Kefeli and Kadyrov, (1971) who suggested that the effects of phenols are primarily on metabolic systems rather than on hormonal ones

Generally, it could be concluded that volkamer micro-cuttings infected the basal part with $A$. rhizogenes cells followed by cultured on MS basal medium supplemented with vitamin $B_{12}$ solution at $1.5 \mathrm{mg} / \mathrm{L}$ " $\mathrm{TV}_{5}$ " resulted in the best rooting performance, average roots number, roots diameter as well as roots fresh and dry weights. Moreover this combined treatment also increased average micro-cuttings rooting\% and roots length over the untreated control micro-cuttings cultured in vitro on basal MS (1962) medium. The superiority of this combined treatment could be attributed to a kind of synergistic effect between infection and vitamin $B_{12}$ at $1.5 \mathrm{mg} / \mathrm{L}$. This characterized function caused an increasing effect on chemical constituents which play an important role on inducing roots on the treated micro-cuttings. The treatment of infection with bacterial cells before micro-cuttings culturing " $\mathrm{T}_{1}$ " can be ranked the next effect in that respect, since it enabled early rooting (15 days) and measured the middle values for adventitious root parameters along with the most amenable for most shoot parameters. Moreover, it succeeded to increase the determined chemical constituents and the calculated $\mathrm{C} / \mathrm{N}$ ratio.

Consequently, the present research succeeded to introduce an additional modern technique that can help in overcoming the difficulty to root cuttings which is still one of the major obstacles to successful micro-propagation of the most economically important fruit trees. Furthermore, this characterized technique provides uniform rootstock seedlings true to type that insure complete similar effects on the grafted or budded scions. In addition it improves performance of the induced adventitious roots as well as increases rooting $\%$ and shoot multiplication parameters in order to achieve successful transfer seedlings to the field. This in turn makes volkamer lemon good rootstock if the propagated trees are desirable.

\section{REFERENCES}

A.O.A.C. (1984). "Official Methods of Analysis" $13^{\text {th }}$ Ed. Published by the Association of Official Analytical chemists, Washington. Dc. U.S.A.

Abou Rayya M.S.; Kassem N.E. and Ali E.A.M. (2010) Rooting induction of soft wood and almond micro-cutting using Agrobacterium rhizogenes. Science and Biotechnology, 76: 758-763.

Aronen, T.S.; Haggman, H.M. and Salonen, M., (1996) Rooting of scots pine fascicular shoots by Agrobacterium rhizogenes. Forest Genetics, 3:1322.

Award, M.A.; DeJager A.; Van Derplace L.H.W. and VanDerkrol. A.R. (2001). Flavonoid and chlorogenic acid changes in skin of Elstar and Jonagold apples during development and ripening.J.Sci.Hort.,90:6983.

Bleasdale, J.K.A. (1984). Plant Physiology In Relation to Horticulture. $2^{\text {nd }}$ Ed. The MacMillan Press Ltd. London. Pp: 92-95. 
Bouillenne, R. and Bouillenne-Walrand, M. (1955). Auxin et bouturage, Rpt. $14^{\text {th }}$ Int. Hort. Cong. Vol. 1, Pp. 231-238.

Breen, P. J. and Muraoka, T. (1973). Effect of indolebutyric acid on distribution of 14C-phytosynthase in softwood cuttings of "Marianna 2624" plum. J. Amer. Soc. Hort. Sci., 98: 436-439.

Caboni, E.; Lauri, P.; Tonelli, M.; Falasca, G. and Damiano, C. (1996). Root induction by Agrobacterium rhizogenes in walnut. Plant Science, 118:203-208.

Cannon, M.J.; Myszka D.G.; Bagnate D.J.; Alpers D.H.; West F.G. and Grissom C. B. (2002). Equililpium and kinetic analyses of the interactions between vitamin $\mathrm{B}_{12}$ binding proteins and colalamins by surface plasman resonance .Analytical Biochemistry, 305:1-9.

Damiano, C. and Monticelli, S. (1998). In vitro fruit trees rooting by Agrobacterium rhizogenes wild type infection. Electron J. Biotechnol., 1(2): 338-345.

Damiano, C.; Archilletti, T.; Caboni, E.; Lauri, P.; Falasca, G.; Mariotti, D. and Ferraiolo, G. (1995). Agrobacterium mediated transformation of almond: in vitro rooting through localised infection of $A$. rhizogenes Acta Horticulturae, 392:161-169.

Danckwardi-lillistorium, C. (1957). Kinetin-induced shoot formation from isolated roots of Isatistinctoria. Physiol. Plant, 10: 794-797.

Dobigny A.; Ambrase A.; Haicour R.; David C.; Rossignol L. and Sinachakt, D. (1995). Transformation of potato using Mannopine and Cucumpine strains of Agrobacterium rhizogenes. Plant cell, Tissue and Organ Culture, 40:225-230.

Draper, J.; Roderick, S.; Philop, A. and Walden, R. (1988) Plant Gene Expression. ALaboratory Manual. Blackwell. Boston, MA, pp 355 USA..

Elchel, J.; Gonzales, J.C.; Hotze, M.; Matthews, R.G. and Schoder J. (1995). Vitamin- $B_{12}$ - Independent methionine synthase from a higher plant (Catharanthuoroseus) maleculer characterization, regulation, heterologous expression and enzyme properties. Eur. J. Biochem., 23 : 1053-1058.

Fadle, M. S. and Hartmann, H. T. (1967). Isolation, purification and characterization of an endogenous root-promoting factor obtained from the basal sections of pear hardwood cuttings. Plant Physiol., 42: 541549.

Felker, C.P.; Medinab, D.; Soulierb, C.; Veliccec, G.; Velardea, M. and Gonzalezb, C. (2005). A survey of environmental and biological factors (Azospirillum spp, Agrobacterium rhizogenes, and Pseudomonas aurantiaca) for their influence in rooting cuttings of Prosopis alba clones. Journal of Arid Environments, 61:227-247.

Galle, E. E. C. (1965). Effect of auxin on the history and metabolism of leaf cuttings of Brassica oleracea, var. botrytis., M.S. Thesis, Univ. stellenboch (Union of Africa).

GenStat Release 11.1 ( PC/Windows) Copyright 2008, VSN International Ltd., 5 waterhouse street, Hemel Hempstead HP11 ES, UK. 
Gomez, K.A. and Gomez, A.A. (1984). Statistical Procedures For the Agriculture Research. John Wiley Sons, Int. Rice Res. Tnst. Book, 2 Ed.

Gutierrez-Pesce, P.; Taylor, K.; Muleo, R. and Rugini, E. (1998). Somatic embryogenesis and shoot regeneration from transgenic roots of cherry rootstock Colt (Prunus avium X $P$. pseudocerasus) mediated by pRi1855 T-DNA of Agrobacterium rhizogenes. Plant Cell Reports, 17:581-5.

Haggman, H.M. and Aronen, T.S. (2000). Agrobacterium rhizogenes for rooting recalcitrant woody plants. Molecular Biology of Woody Plants, 2. Kluwer Academic Publishers, The Netherlands, pp. 47-78.

Hambrick, C.E.; Davies, F.T.; Jr., and Pemberton, H.B. (1985). Effect of cutting position and carbohydrate/nitrogen ratio on seasonal rooting of Rosa multiflora. HortScience, 20:570.

Hartmann, H.T.; Kester, D.E.; Davies, F.T. and Geneve, R.L. (2010). Hartmann and kester's Plant Propagation: Principle and Practices. $8^{\text {th }}$ ed Prentice-Hall.Pp. 869.

Hartmann, H. T. and Kester, D. E. (1968). Plant propagation, Principles and Practices. Prentice-Hall, Inc., Englewood Cliffs, New Jersey, Second Edition Pp.702.

Hedge, I.E. and Hofreiter, B.T. (1962). "carbohydrate chemistry i7 (Eds Whistler R.L. and Be Miller, J.N.) Academic Press New York.

Hess, C. E. (1962). Characterization of the rooting co-factors extracted from Hedra helix L. and Hibiscus rosa-sinensis L. Proc. $16^{\text {th }}$ Int.Hort. Cong., Pp. 382-388.

Hussein, M. M. M. (2008). Studies on the rooting and the consequent plant growth on the stem cuttings of Thunbergia grandiflora (Roxb ex Rott.) Roxb. 1- Effect on different planting date. World Journal of Agricultural Science, 4(2): 125-132.

Jones, I. R.; Benton, I.; Wolf, B. and Mills, H.A. (1991). Plant analysis. Hand book methods of plant analysis and inter-predation. Micro-Macro. Publishing, inc., USA. pp, 30-34.

Kadota, M.; Imizu, K. and Hirano, T. (2001). Double-phase in vitro culture using sorbitol increases shoot proliferationand reduces hyperhydricity in Japanese pear. Sci hort., 89(3): 207-215

Kefeli, V. I. and Kadyrov, C. S. (1971). Natural growth inhibitors, their chemical and physiological properties., Ann. Rev. Plant Physiol., 22: 185-196.

Kim, Y.J.; Pyo, H.K. and Yeam, D.Y. (1977). Physiological mechanism of seasonal fluctuation of rooting in korean boxwood (Buxus microphylla var. koreana Nakai) cutting. J. Kor. Soc. Hort. Sci., 18: 63-87.

Kondo, S.; Katayama R. and Uchino, K. (2005). Antioxidant activity in Meiwa Kumquat as affected by environmental and growing factors. Environ. Exp. Bot., 54: 60-68.

Mahros, O. M. (2000). Rooting and growth of some types of bougainvillea cuttings under IBA stimulation. Assuit J. Agric. Sci., 31: 19-37.

Malick, C.P. and Singh, M.B. (1980). "Plant Enzymology and Histo Enzymology Kalyari" Publishers New Delhi pp, 286. 
McAfee, B.J.; White, E.E.; Pelcher, L.E. and Lapp, M.S. (1993). Root induction in pine (Pinus) and Larch (Larix) spp. using Agrobacterium rhizogenes. Plant Cell, Tissue and Organ Culture, 34:53-62.

Mingshan, L. and David, W.M. (2003). Root induction in radiate Pine using Agrobacterium rhizogenes. Electron. J. Biotechnol., 6(3): 251-258.

Murashige, T. and Skoog, F. (1962). A revised medium for rapid growth and bioassays with tobacco tissue cultures. Physiol Plant, 15:473-97.

Nag, N.; Saha, K. and Choudhuri, M.A. (2001). Role of auxin and polyamines in adventitious root formation in relation to changes in compounds involved in rooting J. Plant Growth Regul., 20: 182-194.

Peterburgski, A.V. (1968). Hand Book of Agronomic Chemistry. Kolas publishing House, Moscow, (in Russian), pp. 29-86.

Rugini, E.; Jacoboni, A. and Luppino M. (1993). Role of basal shoot darkening and exogenous putrescine treatments on in vitro rooting and on endogenous polyamine changes in difficult-to-root woody species. Scientia Horticulturae, 53:63-72.

Rugini, E.; Pellegrineschi, A.; Mencuccini, M. and Mariotti, D. (1991). Increase of rooting ability in the woody species kiwi (Actinidia deliciosaA. Chev.) by transformation with Agrobacterium rhizogenes rol genes. Plant Cell Reports, 10:291-295.

Sato, K.; Maitani, T. and Yoshihira, K. (1991). Uptake of arsenic by cultured hairy roots of Rubia tinctorum from liquid medium, Journal of Food Hygienic Society of Japan, 32(5): 414-415.

Stoutimyer, V.T. and Close, A.W. (1946). Rooting cuttings and germinating seeds under fluorescent and cold cathode light. Proc. Amer. Sec. Hort. Sci., 48:309-325.

Strobel, G.A. and Nachimas, A. (1985). Agrobacterium rhizogenes promotes the initial growth of bare root stock almond. Journal General Microbiology, 131:1245-1249.

Sutter, E.G. and Luza, J. (1993). Developmental anatomy of roots induced by Agrobacterium rhizogenes in Malus pumila 'M26' shoots grown in vitro. International Journal of Plant Sciences, 154:59-67.

Tahir, F.M.; Pervez, M.A.; Pervez, M.A. and Ahamad, R. (1998). Effect of growth regulators on rooting performance of stem cuttings in guava (Psdium guajave L.). Pakistan Journal of Biological Sciences Pakistan, 1(2): 132-133.

Yongkweon, Y. and KiSum, K. (1996). Seasonal variation in rooting ability, plant hormones, carbohydrate, nitrogen, starch and soluble sugar contents in cuttings of white forsythia (Abiliophyllum distichum Nakai.). J. Kor.Soc.Hort. Sci., 37(4): 554-560.

Zhu, L.H.; Ahlman, A.; Li, X.Y. and Welander, M. (2001). Integration of the rolA gene into the genome of the vigorous apple rootstock $A 2$ reduced plant height and shortened internodes. Journal of Horticultural Science and Biotechnology, 76: 758-763. 


\section{العوامل البيولوجية لتعظيم التجذير وتضاعف الأفرخ على العقل الاقيقة لأصل \\ ليمون الفولكاميريانا}

لطيف جرجس سمعان ومحمود ابراهيم القاضى وأمير محمد شعلان ولمياء محمود محمد

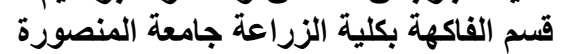

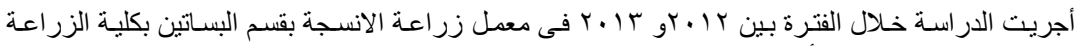

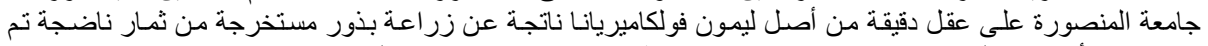

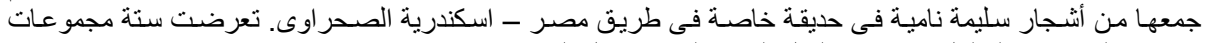

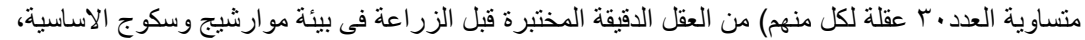

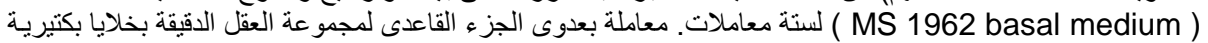
من أحد سلالات الاجروبكتبريوم ريزو جينس

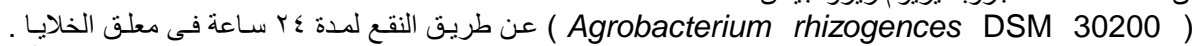

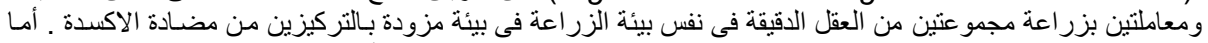

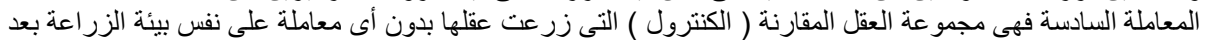

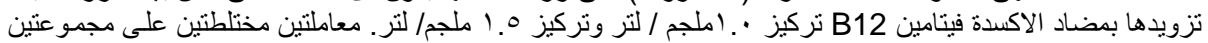

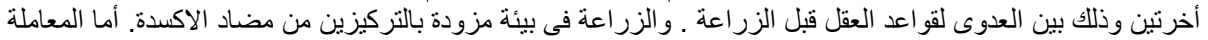

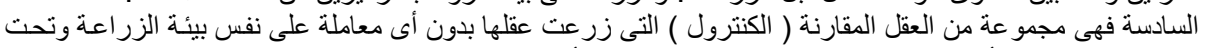

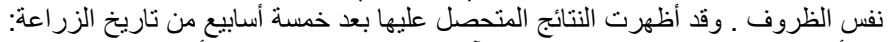

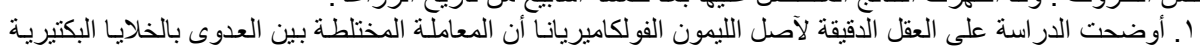

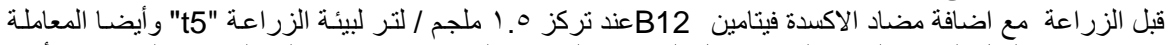

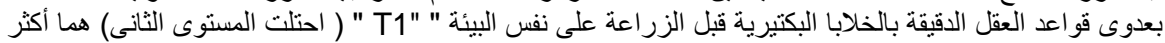

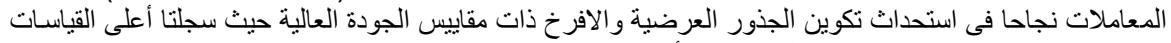

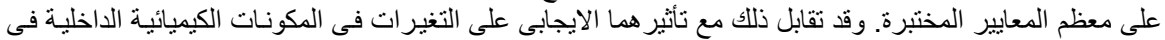

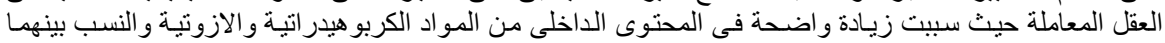

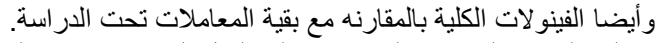

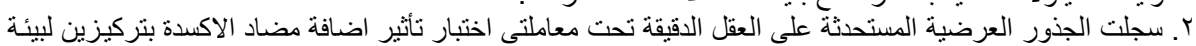

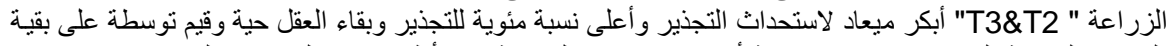

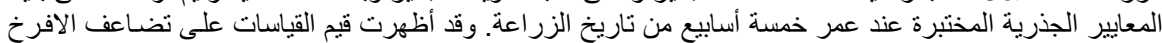

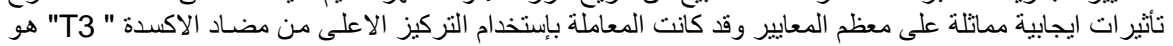
الافضل.

r. اظهرت النتائج قياسـات معاكسة للمعاملة النختلط المتميزة " T5 " على صفئ صفتى بداية التجذير و النسبة المئوية للعقل

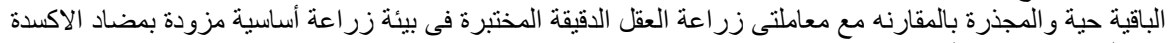

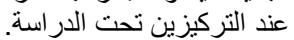

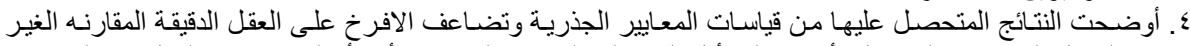

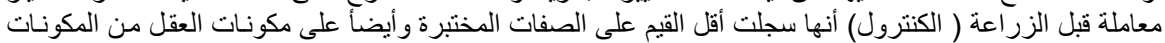

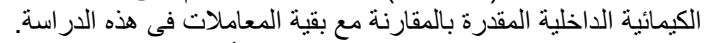

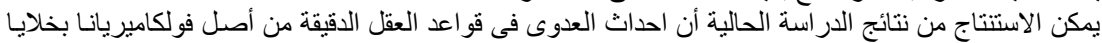

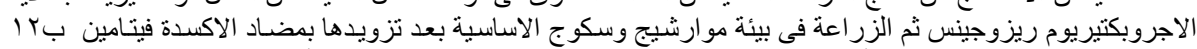

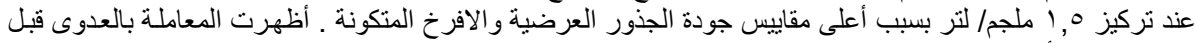

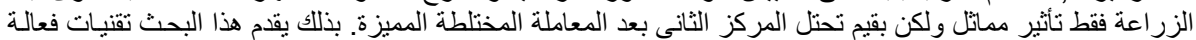

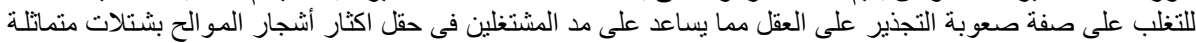

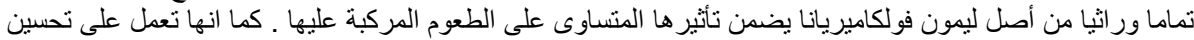

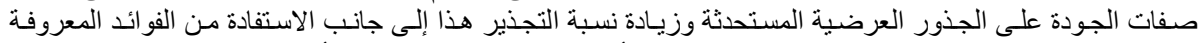

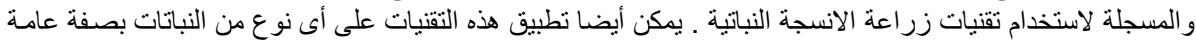

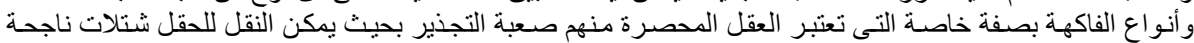

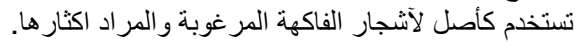

كلية الزراعة - جامعة المنصورة قام بتحكيم البحث لأبدار كلية زراعةمشتهز - جامعة بنها 